\title{
Reversible Dihydrogen Activation and Hydride Transfer by a Uranium Nitride Complex
}

\author{
Marta Falcone, Lok Nga Poon, Farzaneh Fadaei Tirani, and Marinella Mazzanti*
}

\begin{abstract}
Cleavage of dihydrogen is an important step in the industrial and enzymatic transformation of $\mathrm{N}_{2}$ into ammonia. The reversible cleavage of dihydrogen was achieved under mild conditions (room temperature and 1 atmosphere of $\mathrm{H}_{2}$ ) by the molecular uranium nitride complex, [Cs $\{U(O S i-$ $\left.\left.\left.\left(\mathrm{O}^{t} \mathrm{Bu}\right)_{3}\right)_{3}\right\}_{2}(\mu-N)\right] \mathbf{1}$, leading to a rare hydride-imide bridged diuranium $(I V) \quad$ complex, $\quad\left[\mathrm{Cs}\left\{\mathrm{U}\left(\mathrm{OSi}\left(\mathrm{O}^{t} \mathrm{Bu}\right)_{3}\right)_{3}\right\}_{2}(\mu-H)(\mu-\right.$ $\mathrm{NH})], 2$ that slowly releases $\mathrm{H}_{2}$ under vacuum. This complex is highly reactive and quickly transfers hydride to acetonitrile and carbon dioxide at room temperature, affording the ketimide- and formate-bridged $U^{I V}$ species $[\mathrm{Cs}\{\mathrm{U}(\mathrm{OSi}$ $\left.\left.\left.\left(\mathrm{O}^{t} \mathrm{Bu}\right)_{3}\right)_{3}\right\}_{2}(\mu-\mathrm{NH})\left(\mu-\mathrm{CH}_{3} \mathrm{CHN}\right)\right], \quad 3$ and $\quad[\mathrm{Cs}\{\mathrm{U}(\mathrm{OSi}-$ $\left.\left.\left.\left(\mathrm{O}^{t} \mathrm{Bu}\right)_{3}\right)_{3}\right\}_{2}(\mu-\mathrm{HCOO})(\mu-\mathrm{NHCOO})\right], 4$.
\end{abstract}

$\boldsymbol{H}$ eterolytic $\mathrm{H}_{2}$ cleavage is an important step in many reactions promoted by enzymes or synthetic catalysts. ${ }^{[1]}$ Hydrogen activation is crucial in the industrial HaberBosch process that is used in the production of ammonia from $\mathrm{N}_{2}$ and $\mathrm{H}_{2}$ and is also important in nitrogen fixation by nitrogenase enzymes, which is enabled by hydride-containing intermediates. ${ }^{[2]}$ Such hydride intermediates are also believed to play a role in the reduction of other substrates such as $\mathrm{CO}_{2}$ or nitriles effected by these enzymes. ${ }^{[3]}$ Moreover, hydrogenolysis by metal nitride intermediates is believed to be a key step in the Haber-Bosch process. ${ }^{[4]}$ However, only three examples of heterolytic splitting of $\mathrm{H}_{2}$ by a nitride complex have been reported so far. ${ }^{[5]}$ The reactivity of uranium nitrides is of high current interest because of the relevance of $\mathrm{U}^{\mathrm{III}}$ nitride (UN) in nuclear industry ${ }^{[6]}$ and because of their activity as catalysts ${ }^{[7]}$ in the formation of ammonia from $\mathrm{N}_{2}$ and $\mathrm{H}_{2}$. Moreover, molecular nitride complexes of uranium can effect dinitrogen reduction and stoichiometric $\mathrm{N}_{2}$ conversion to $\mathrm{NH}_{3}{ }^{[7,8]}$ and $\mathrm{N}-\mathrm{C}$ formation reactions under mild conditions. ${ }^{[9]}$ However, despite the increasing number of characterized uranium nitride complexes ${ }^{[10]}$ the study of the reactivity of these systems is still in its infancy and in particular the reaction with dihydrogen has never been explored.

In view of the ability of uranium nitrides to effect the transformation of dinitrogen to ammonia, we became interested in studying the reaction of uranium nitrides with $\mathrm{H}_{2}$ and

[**] M. Falcone, L. N. Poon, Dr. F. Fadaei Tirani, Prof. M. Mazzanti Institut des Sciences et Ingénierie Chimiques

Ecole Polytechnique Fédérale de Lausanne (EPFL)

1015 Lausanne (Switzerland)

E-mail: marinella.mazzanti@epfl.ch

(iD) $\mathrm{S}$ Supporting information and the ORCID identification number(s) for the author(s) of this article can be found under:

https://doi.org/10.1002/anie.201800203. in the possibility of obtaining a highly reactive uranium hydride-imide complex.

Notably, despite the relevance of such species in biological and industrial dinitrogen reduction, their formation from $\mathrm{H}_{2}$ addition to metal nitrides or metal-dinitrogen complexes remains extremely rare. ${ }^{[5 a, 11]}$ Moreover, despite the fact that the seminal work of Andersen and Marks on organometallic uranium hydrides goes back to the early $80 \mathrm{~s},{ }^{[12]}$ uranium hydrides remain rare and most of the reported examples contain carbocyclic ligands. ${ }^{[12 c, 13]}$ Herein we show that the bifunctional Lewis acid-base character of the $\mathrm{U}-\mathrm{N}$ bond in the multimetallic $\mathrm{U}^{\mathrm{IV}}$ complex $\left[\mathrm{Cs}\left\{\mathrm{U}\left(\mathrm{OSi}\left(\mathrm{O}^{\mathrm{t}} \mathrm{Bu}\right)_{3}\right)_{3}\right\}_{2}(\mu-\mathrm{N})\right]$ $\mathbf{1}^{[14]}$ leads to the facile, reversible heterolytic cleavage of dihydrogen under ambient conditions and to the reversible formation of a parent imide-hydride complex that can transfer the hydride to acetonitrile and $\mathrm{CO}_{2}$.

When a toluene solution of the previously reported ${ }^{[14]}$ complex $\mathbf{1}$ is exposed to 1 atmosphere of hydrogen, the solution turns from brown to yellow within 15 minutes and the proton NMR spectrum shows the disappearance of the siloxides signal of $\mathbf{1}$ and the appearance of a new signal at $0.32 \mathrm{ppm}$, assigned to the siloxide ligands of complex [Cs $\{\mathrm{U}-$ $\left.\left.\left(\mathrm{OSi}\left(\mathrm{O}^{\mathrm{t}} \mathrm{Bu}\right)_{3}\right)_{3}\right\}_{2}(\mu-\mathrm{H})(\mu-\mathrm{NH})\right], 2$ (Scheme 1$)$. The resonance

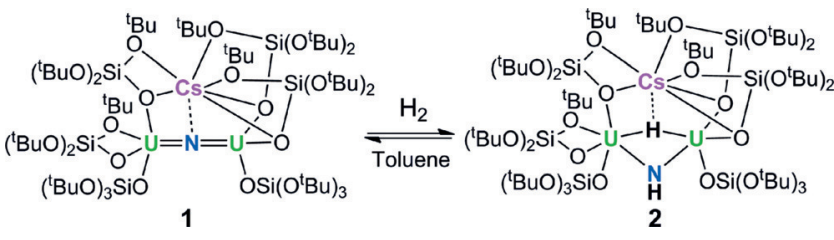

Scheme 1. Reversible cleavage of $\mathrm{H}_{2}$ by 1 to afford the di-uranium(IV) hydride-imide product 2 .

at $571.3 \mathrm{ppm}$ in the ${ }^{1} \mathrm{H}$ NMR spectrum of $\mathbf{2}$ is assigned to the $\mathrm{U}^{\mathrm{IV}}$-bound hydride and its value is consistent with those reported for other $\mathrm{U}^{\mathrm{IV}}$ hydride complexes. ${ }^{[13 \mathrm{~g}, 15]}$ This resonance is absent in the ${ }^{1} \mathrm{H}$ NMR spectrum of the deuterated analogue $\quad\left[\mathrm{Cs}\left\{\mathrm{U}\left(\mathrm{OSi}\left(\mathrm{O}^{\mathrm{t}} \mathrm{Bu}\right)_{3}\right)_{3}\right\}_{2}(\mu-\mathrm{D})(\mu-\mathrm{ND})\right], \quad \mathbf{D}_{\mathbf{2}}-\mathbf{2}$. Removal of the gas in the headspace after reaction of 1 with $\mathrm{H}_{2}$ results in slow $\mathrm{H}_{2}$ loss and formation of the nitride complex 1. Crystals of complex 2 also loose $\mathrm{H}_{2}$ once removed from the solution resulting in the isolation of complexes $\mathbf{1}$ and 2 co-crystallized in 30:70\% ratio (see Supporting Information). However, loss of $\mathrm{H}_{2}$ could be avoided by maintaining at $-40^{\circ} \mathrm{C}$ the crystals of 2 , obtained at $-40^{\circ} \mathrm{C}$ under 1 atm $\mathrm{H}_{2}$, during crystal mounting in oil and by performing X-ray data collection at $-133{ }^{\circ} \mathrm{C}$. The facile and reversible activation of $\mathrm{H}_{2}$ by complex $\mathbf{1}$ is remarkable. Notably, in the only example 
reported so far of cooperative $\mathrm{H}_{2}$ activation by a bifunctional metal nitride, the $\mathrm{H}_{2}$ cleavage is not reversible. ${ }^{[5]}$

The molecular structure of $\mathbf{2}$ (Figure 1 ) could be determined by the X-ray analysis of crystals of $\mathbf{2}$, and it shows

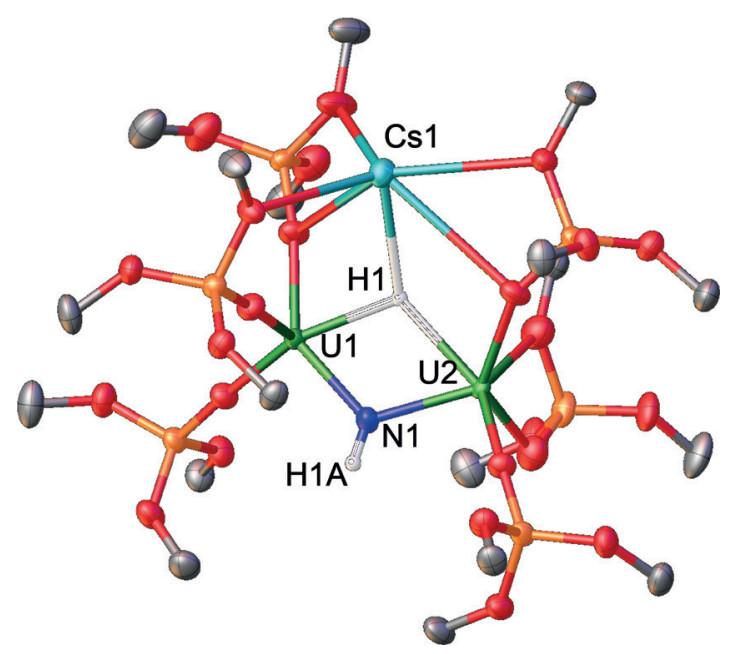

Figure 1. Molecular structure of $\left[\mathrm{Cs}\left\{\mathrm{U}\left(\mathrm{OSi}\left(\mathrm{O}^{t} \mathrm{Bu}\right)_{3}\right)_{3}\right\}_{2}(\mu-\mathrm{H})(\mu-\mathrm{NH})\right]$, $2 .^{[25]}$ Ellipsoids are set at $50 \%$ probability; methyl groups are omitted for clarity.

a dinuclear $\mathrm{U}^{\mathrm{IV}}$ complex bridged by an imido and a hydrido ligand. Electron density that could be assigned to the imide and to the hydride was located, and both groups were refined without imposing any constraints. A Cs cation is bound by the siloxide ligands resulting in a dissymmetric structure analogous to that found in the nitride complex 1. Notably, two siloxide ligands bridge the U1 and Cs centers binding the Cs in a bidentate fashion while only one siloxide ligand binding the Cs cation in a bidentate fashion bridges U2 and Cs. The Cs cation was found in the apical position of the nitride at a $\mathrm{Cs}-\mathrm{N}$ distance of 3.393(4) $\AA$ in $\mathbf{1}$, while in $\mathbf{2}$ it lies at the apical position of the hydride ligand with a $\mathrm{Cs}-\mathrm{H}$ distance of 2.73(6) $\AA$ and is located at a non-bonding distance of 4.821(3) A from N1. Moreover, the U-N-U angle changes dramatically from linear in complex $\mathbf{1}$ (U-N-U angle: $\left.170.2(3)^{\circ}\right)$ to bent in the diamond core geometry of complex 2 (U-N-U angle: $\left.117.5(3)^{\circ}\right)$ and the $\mathrm{U}-\mathrm{N}$ bond distances are significantly elongated in 2 (2.187(3), 2.256(4) A) compared to those found in $\mathbf{1}(2.058(5)-2.079(5) \AA)$. These data are in agreement with the presence of a protonated $\mathrm{NH}$ group and the $\mathrm{U}-\mathrm{NH}$ distances are in the range of those found in diuranium(IV) imido bridged complexes (2.156(8)$2.315(8) \AA) .{ }^{[16]}$ One terminal parent imido $\mathrm{U}^{\mathrm{IV}}$ complex is known, ${ }^{[17]}$ but a bridging parent imido- $\mathrm{U}^{\mathrm{IV}}$ linkage was not characterized previously. In contrast, the bridging parent imido $U^{V} U^{V}\left[K_{2}\left\{\left[\mathrm{U}\left(\mathrm{OSi}\left(\mathrm{O}^{\mathrm{t}} \mathrm{Bu}\right)_{3}\right)_{3}\right]_{2}(\mu-\mathrm{NH})\left(\mu-\eta^{2}: \eta^{2}-\mathrm{N}_{2}\right)\right\}\right]$ and $\mathrm{U}^{\mathrm{IV}} \mathrm{U}^{\mathrm{V}} \quad\left[\mathrm{K}_{2}\left\{\left[\mathrm{U}\left(\mathrm{OSi}\left(\mathrm{O}^{\mathrm{t}} \mathrm{Bu}\right)_{3}\right)_{3}\right]_{2}(\mu-\mathrm{NH})_{2}(\mu-\mathrm{Cl})\right\}\right]$ complexes were previously isolated in our group by protonation of the nitride-hydrazide complex $\left[\mathrm{K}_{3}\left\{\left[\mathrm{U}\left(\mathrm{OSi}\left(\mathrm{O}^{t} \mathrm{Bu}\right)_{3}\right)_{3}\right]_{2}(\mu-\mathrm{N})(\mu-\right.\right.$ $\left.\left.\left.\eta^{2}: \eta^{2}-\mathrm{N}_{2}\right)\right\}\right]{ }^{[8]}$ The hydride bridges the two uranium cations (U-U, $3.786 \AA$ ) in a non-symmetric fashion (U-H 2.18(6) and 2.36(6) $\AA$ ) with the shorter distance being comparable to those determined by neutron diffraction studies for the
$\left[\left(\mathrm{C}_{5} \mathrm{Me}_{5}\right)_{2} \mathrm{UH}_{2}\right]_{2}$ complex $(2.134(9) \AA)^{[18]}$ where the hydride bridges the two uranium centers in a symmetric fashion. Complex $\mathbf{2}$ is a rare example of imide-hydride bridged complex. ${ }^{[5 a, 11,19]}$ Such species are very relevant as probable intermediate in $\mathrm{N}_{2}$ hydrogenation to yield $\mathrm{NH}_{3} \cdot{ }^{[19 b, 20]}$

Complex 2 displays a rich reactivity that both unambiguously confirms the presence of the hydride-imide core in $\mathbf{2}$ and demonstrates the ability of $\mathbf{2}$ to effect hydride transfer reactions.

Complex 2 reacts with acetonitrile and carbon dioxide to yield insertion products. The addition of $\mathrm{MeCN}$ to a toluene solution of $\mathbf{2}$ (Scheme $2 \mathrm{a}$ ) led to the formation of the bridging

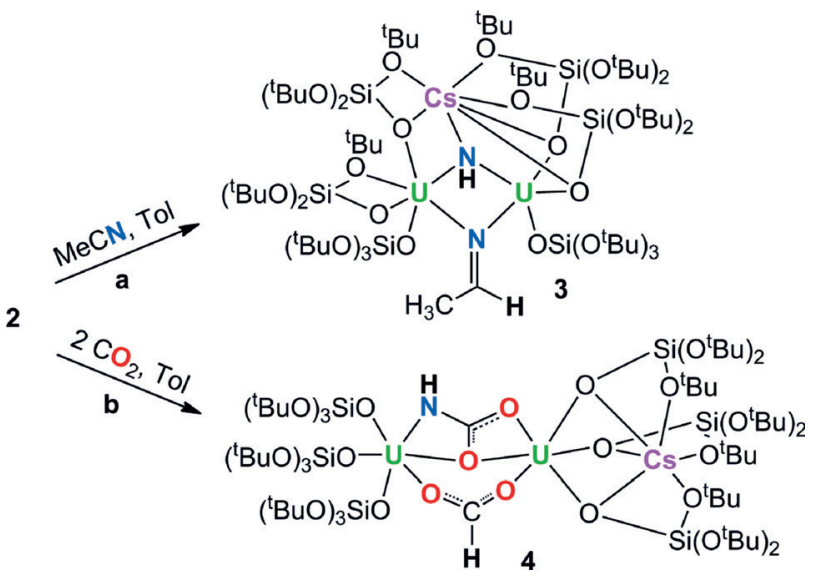

Scheme 2. In situ reactions of $\mathbf{2}$ with a) acetonitrile to give $\mathbf{3}$ and b) 2 equiv of carbon dioxide to give 4 .

imido-ketimide complex $\left[\mathrm{Cs}\left\{\mathrm{U}\left(\mathrm{OSi}\left(\mathrm{O}^{\mathrm{t}} \mathrm{Bu}\right)_{3}\right)_{3}\right\}_{2}(\mu-\mathrm{NH})(\mu-\right.$ $\left.\mathrm{CH}_{3} \mathrm{CHN}\right)$ ], 3, that was isolated in high yield $(85 \%)$ as a yellow crystalline solid. Thus, the hydride addition to the acetonitrile results in the two-electron reduction of the nitrogen-carbon triple bond. The solid-state structure of $\mathbf{3}$ (Figure 2) shows the presence of two uranium ions bridged by an imido and a ketimido (or azavinylidene) group. A cesium

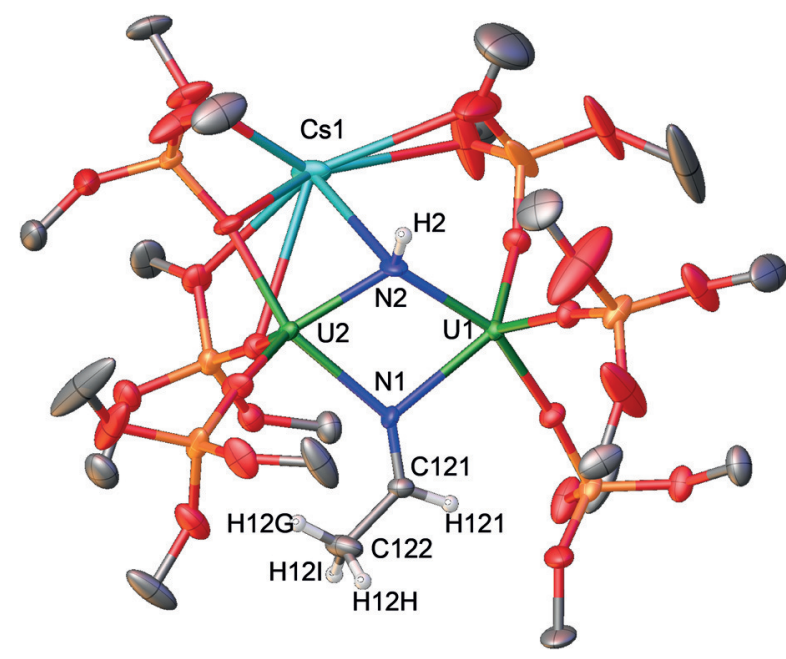

Figure 2. Molecular structure of $\left[\mathrm{Cs}\left\{\mathrm{U}\left(\mathrm{OSi}\left(\mathrm{O}^{t} \mathrm{Bu}\right)_{3}\right)_{3}\right\}_{2}(\mu-\mathrm{NH})(\mu\right.$ $\left.\mathrm{CH}_{3} \mathrm{CHN}\right)$ ], 3. ${ }^{[25]}$ Ellipsoids are set at $50 \%$ probability; methyl groups are omitted for clarity. 
cation binds in a dissymmetric fashion the imido nitrogen and the siloxide ligands. The carbon atom $\mathrm{C} 121$ has a trigonal planar geometry and the $\mathrm{C} 121-\mathrm{N} 1$ distance of $1.273(7) \AA$ is consistent with a carbon-nitrogen double bond. The pseudo tetrahedral geometry of the $\mathrm{N} 2$ atom and the $\mathrm{U}-\mathrm{N} 2$ distances (U1-N2 2.247(4) and U2-N2 2.209(5) A) are in agreement with the presence of an imido group $\mathrm{NH}$, indicating that the $\mathrm{NH}$ group is not involved in the reactivity with MeCN. The IR spectrum shows a peak at $1629 \mathrm{~cm}^{-1}$ assigned to the $\mathrm{N}-\mathrm{C}$ double bond stretching. The insertion of nitriles into the $\mathrm{U}-\mathrm{C}$ bond has been used by Kiplinger and co-workers. ${ }^{[21]}$ as a convenient method for the synthesis of mono- and multimetallic ketimide complexes. Formation of a ketimide ligand from the insertion of the nitrile triple bond into a uranium hydride complex was also reported previously but the insertion products were not crystallographically characterized. ${ }^{[13 \mathrm{~g}]}$ The ability of $\mathbf{2}$ to perform hydride transfer reactivity and the consequent reducing behavior of the hydride towards substrates were confirmed in the reaction of $\mathbf{2}$ with carbon dioxide. Addition of two equivalents of $\mathrm{CO}_{2}$ (Scheme $2 \mathrm{~b}$ ) to 2 led to the formation of complex $\left[\mathrm{Cs}\left\{\mathrm{U}\left(\mathrm{OSi}\left(\mathrm{O}^{\mathrm{t} B u}\right)_{3}\right)_{3}\right\}_{2}(\mu-\right.$ $\mathrm{HCOO})(\mu-\mathrm{NHCOO})], \mathbf{4}$ in $44 \%$ yield $)$. The addition of less than 2 equivalent of $\mathrm{CO}_{2}$ shows only the presence of unreacted $\mathbf{2}$ and 4.

The solid-state structure of $\mathbf{4}$ (Figure 3) shows the presence of two $\mathrm{U}^{\mathrm{IV}}$ cations bridged by a formate and a dianionic carbamate group. A cesium cation is also bound in the pocket formed by three siloxides bound to U1. Complex 4 is only the second example of a crystallographically characterized formate complex obtained from the insertion of $\mathrm{CO}_{2}$ into a $\mathrm{U}-\mathrm{H}$ bond and the first one containing a bridging formate. ${ }^{[13 a]}$ The $\mathrm{U}-\mathrm{O}$ distances for the bridging formate in $\mathbf{4}$ $(2.409(3)$ and $2.356(3) \AA)$ are slightly shorter than those found in the reported terminal formate $(2.451(3) \AA)$. The proton of the formate was located by X-ray diffraction and was identified in the ${ }^{1} \mathrm{H}$ NMR spectrum. The concomitant cycloaddition of $\mathrm{CO}_{2}$ to the parent imido linkage affords a bridging $\kappa^{3}$-carbamate group. This reactivity is a rare example of cycloaddition of $\mathrm{CO}_{2}$ to a metal imido complex ${ }^{[22]}$

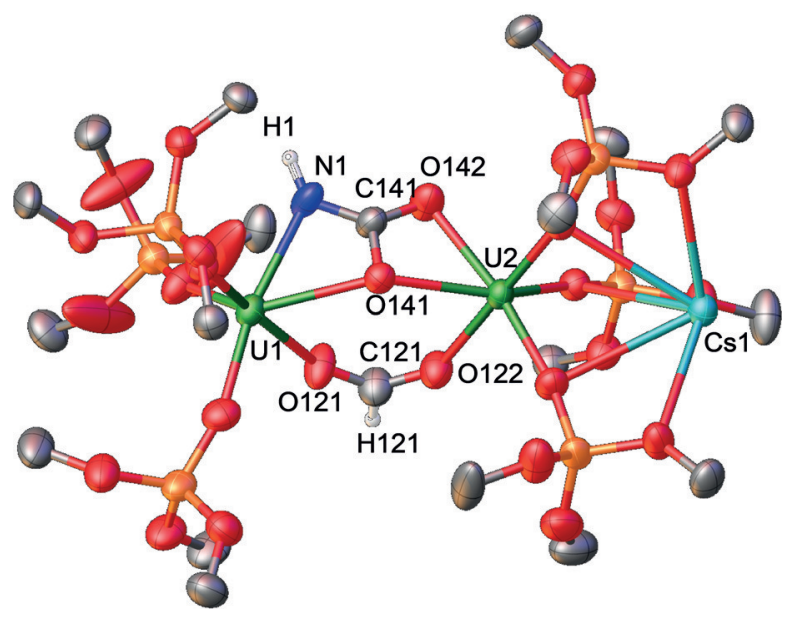

Figure 3. Molecular structure of $\left[\mathrm{Cs}\left\{\mathrm{U}\left(\mathrm{OSi}\left(\mathrm{O}^{\mathrm{t}} \mathrm{Bu}\right)_{3}\right)_{3}\right\}_{2}(\mu-\mathrm{HCOO})(\mu\right.$ $\mathrm{NHCOO})], 4{ }^{[25]}$ Ellipsoids are set at $50 \%$ probability; methyl groups are omitted for clarity. and differs from that reported for $\mathrm{U}^{\mathrm{IV}}$-bound terminal bulky aryl imido groups $(\mathrm{U}=\mathrm{N}-\mathrm{Ar})$ that results in $\mathrm{N}=\mathrm{C}$ bond methathesis and extrusion of the cyanate via a proposed carbamate intermediate. ${ }^{[23]}$ The low steric pressure of the $\mathrm{NH}$ group and its bridging mode result in a high stability of the $\kappa^{3}-$ $\mathrm{O}, \mathrm{O}, \mathrm{N}$-carbamate group. A few examples of $\mathrm{U}^{\mathrm{IV}}$ carbamate have been reported but they all present monoanionic $\kappa^{2}-\mathrm{O}, \mathrm{O}-$ carbamate groups. ${ }^{[23,24]}$

In summary, we have demonstrated that a polymetallic $\mathrm{U}^{\mathrm{IV}}$ nitride effects the reversible heterolytic activation of dihydrogen in mild conditions (room temperature and 1 atmosphere of $\mathrm{H}_{2}$ ). We have also demonstrated the high reactivity of this species. Notably, the hydride is readily transferred to acetonitrile and $\mathrm{CO}_{2}$ resulting in the substrate reduction. These results anticipate that metal hydride intermediates may play an important role in the uranium catalyzed transformation of $\mathrm{N}_{2}$ and $\mathrm{H}_{2}$ into ammonia and also open new avenues for the development of hydrogenation catalysts.

\section{Acknowledgements}

We thank Euro Solari for carrying out the elemental analyses and Rosario Scopelliti for his contribution to $\mathrm{X}$ ray data collection and analysis.

\section{Conflict of interest}

The authors declare no conflict of interest.

Keywords: cooperativity - dihydrogen activation - hydrides . nitrides $\cdot$ uranium

How to cite: Angew. Chem. Int. Ed. 2018, 57, 3697-3700

Angew. Chem. 2018, 130, 3759-3762

[1] a) M. Rakowski DuBois, D. L. DuBois, Chem. Soc. Rev. 2009, 38, 62-72; b) S. G. Zhang, A. M. Appel, R. M. Bullock, J. Am. Chem. Soc. 2017, 139, 7376-7387.

[2] a) G. J. Kubas, Chem. Rev. 2007, 107, 4152-4205; b) B. M. Hoffman, D. Lukoyanov, Z. Y. Yang, D. R. Dean, L. C. Seefeldt, Chem. Rev. 2014, 114, 4041-4062.

[3] a) Y. Yu, A. R. Sadique, J. M. Smith, T. R. Dugan, R. E. Cowley, W. W. Brennessel, C. J. Flaschenriem, E. Bill, T. R. Cundari, P. L. Holland, J. Am. Chem. Soc. 2008, 130, 6624-6638; b) G. M. Henderson, Recent Advances in Hydride Chemistry (Eds.: M. Peruzzini, R. Poli), Elsevier, New York, 2001, pp. 463-505.

[4] a) R. Schlögl, Angew. Chem. Int. Ed. 2003, 42, 2004-2008; Angew. Chem. 2003, 115, 2050-2055; b) H. P. Jia, E. A. Quadrelli, Chem. Soc. Rev. 2014, 43, 547-564.

[5] a) S. D. Brown, M. P. Mehn, J. C. Peters, J. Am. Chem. Soc. 2005, 127, 13146-13147; b) B. Askevold, J. T. Nieto, S. Tussupbayev, M. Diefenbach, E. Herdtweck, M. C. Holthausen, S. Schneider, Nat. Chem. 2011, 3, 532-537; c) J. Schöffel, A. Y. Rogachev, S. D. George, P. Burger, Angew. Chem. Int. Ed. 2009, 48, $4734-$ 4738; Angew. Chem. 2009, 121, 4828-4832; d) F. S. Schendzielorz, M. Finger, C. Volkmann, C. Wurtele, S. Schneider, Angew. Chem. Int. Ed. 2016, 55, 11417-11420; Angew. Chem. 2016, 128, $11589-11592$. 
[6] G. W. C. Silva, C. B. Yeamans, A. P. Sattelberger, T. Hartmann, G. S. Cerefice, K. R. Czerwinski, Inorg. Chem. 2009, 48, 10635 10642.

[7] a) F. Haber, F. Haber, Ammonia German patent DE 229126 , 1909; b) H. Liu, T. Ghatak, M. S. Eisen, Chem. Commun. 2017, 53, 11278-11297.

[8] M. Falcone, L. Chatelain, R. Scopelliti, I. Zivkovic, M. Mazzanti, Nature 2017, 547, 332-335.

[9] a) M. Falcone, L. Chatelain, M. Mazzanti, Angew. Chem. Int. Ed. 2016, 55, 4074-4078; Angew. Chem. 2016, 128, 4142-4146; b) M. Falcone, C. E. Kefalidis, R. Scopelliti, L. Maron, M. Mazzanti, Angew. Chem. Int. Ed. 2016, 55, 12290-12294 Angew. Chem. 2016, 128, 12478-12482; c) P. A. Cleaves, C. E Kefalidis, M. G. Gardiner, F. Tuna, E. J. L. McInnes, W. Lewis, L. Maron, S. T. Liddle, Chem. Eur. J. 2017, 23, 2950-2959.

[10] a) D. M. King, S. T. Liddle, Coord. Chem. Rev. 2014, 266, 2-15; b) L. Chatelain, R. Scopelliti, M. Mazzanti, J. Am. Chem. Soc. 2016, 138, $1784-1787$; c) N. Tsoureas, A. F. R. Kilpatrick, C. J. Inman, F. G. N. Cloke, Chem. Sci. 2016, 7, 4624-4632; d) L. Maria, I. C. Santos, V. R. Sousa, J. Marcalo, Inorg. Chem. 2015, 54, 9115-9126; e) A. R. Fox, P. L. Arnold, C. C. Cummins, J. Am. Chem. Soc. 2010, 132, 3250-3251; f) P. A. Cleaves, D. M. King, C. E. Kefalidis, L. Maron, F. Tuna, E. J. L. McInnes, J. McMaster, W. Lewis, A. J. Blake, S. T. Liddle, Angew. Chem. Int. Ed. 2014, 53, 10412-10415; Angew. Chem. 2014, 126, $10580-$ 10583 ; g) R. K. Thomson, T. Cantat, B. L. Scott, D. E. Morris, E. R. Batista, J. L. Kiplinger, Nat. Chem. 2010, 2, 723-729; h) D. M. King, F. Tuna, E. J. L. McInnes, J. McMaster, W. Lewis, A. J. Blake, S. T. Liddle, Science 2012, 337, 717-720; i) W. J. Evans, S. A. Kozimor, J. W. Ziller, Science 2005, 309, 1835-1838 j) S. Fortier, G. Wu, T. W. Hayton, J. Am. Chem. Soc. 2010, 132 $6888-6889$

[11] M. P. Shaver, M. D. Fryzuk, J. Am. Chem. Soc. 2005, 127, 500501.

[12] a) H. W. Turner, S. J. Simpson, R. A. Andersen, J. Am. Chem. Soc. 1979, 101, 2782-2782; b) J. M. Manriquez, P. J. Fagan, T. J. Marks, J. Am. Chem. Soc. 1978, 100, 3939-3941; c) P. J. Fagan, J. M. Manriquez, E. A. Maatta, A. M. Seyam, T. J. Marks, J. Am. Chem. Soc. 1981, 103, 6650-6667.

[13] a) J. A. Higgins, F. G. N. Cloke, S. M. Roe, Organometallics 2013, 32, 5244-5252; b) W. J. Evans, E. Montalvo, S. A. Kozimor, K. A. Miller, J. Am. Chem. Soc. 2008, 130, 12258-12259; c) J. C. Berthet, J. F. Lemarechal, M. Lance, M. Nierlich, J. Vigner, M. Ephritikhine, J. Chem. Soc. Dalton Trans. 1992, 1573-1577; d) W. J. Evans, K. A. Miller, A. G. DiPasquale, A. L. Rheingold, T. J. Stewart, R. Bau, Angew. Chem. Int. Ed. 2008, 47, 50755078; Angew. Chem. 2008, 120, 5153-5156; e) H. S. La Pierre,
H. Kameo, D. P. Halter, F. W. Heinemann, K. Meyer, Angew. Chem. Int. Ed. 2014, 53, 7154-7157; Angew. Chem. 2014, 126, 7282 -7285; f) J. K. Pagano, J. M. Dorhout, K. R. Czerwinski, D. E. Morris, B. L. Scott, R. Waterman, J. L. Kiplinger, Organometallics 2016, 35, 617-620; g) M. Ephritikhine, Chem. Rev. 1997, 97, 2193-2242.

[14] C. Camp, J. Pecaut, M. Mazzanti, J. Am. Chem. Soc. 2013, 135, $12101-12111$

[15] C. J. Windorff, M. R. MacDonald, K. R. Meihaus, J. W. Ziller, J. R. Long, W. J. Evans, Chem. Eur. J. 2016, 22, 772-782.

[16] J. G. Brennan, R. A. Andersen, A. Zalkin, J. Am. Chem. Soc. 1988, 110, 4554-4558.

[17] D. M. King, J. McMaster, F. Tuna, E. J. L. McInnes, W. Lewis, A. J. Blake, S. T. Liddle, J. Am. Chem. Soc. 2014, 136, 56195622.

[18] D. Grant, T. J. Stewart, R. Bau, K. A. Miller, S. A. Mason, M. Gutmann, G. J. McIntyre, L. Gagliardi, W. J. Evans, Inorg. Chem. 2012, 51, 3613-3624.

[19] a) T. Kimura, N. Koiso, K. Ishiwata, S. Kuwata, T. Ikariya, J. Am. Chem. Soc. 2011, 133, 8880-8883; b) T. Shima, S. W. Hu, G. Luo, X. H. Kang, Y. Luo, Z. M. Hou, Science 2013, 340, 1549-1552.

[20] M. D. Fryzuk, J. B. Love, S. J. Rettig, V. G. Young, Science 1997, $275,1445-1447$.

[21] a) K. C. Jantunen, C. J. Burns, I. Castro-Rodriguez, R. E. Da Re, J. T. Golden, D. E. Morris, B. L. Scott, F. L. Taw, J. L. Kiplinger, Organometallics 2004, 23, 4682-4692; b) E. J. Schelter, J. M. Veauthier, C. R. Graves, K. D. John, B. L. Scott, J. D. Thompson, J. A. Pool-Davis-Tournear, D. E. Morris, J. L. Kiplinger, Chem. Eur. J. 2008, 14, $7782-7790$.

[22] A. E. Guiducci, C. L. Boyd, E. Clot, P. Mountford, J. Chem. Soc. Dalton Trans. 2009, 5960-5979.

[23] S. C. Bart, C. Anthon, F. W. Heinemann, E. Bill, N. M. Edelstein, K. Meyer, J. Am. Chem. Soc. 2008, 130, 12536-12546.

[24] a) J. A. Higgins Frey, G. N. Cloke, S. M. Roe, Organometallics 2015, 34, 2102-2105; b) E. M. Matson, P. E. Fanwick, S. C. Bart, Organometallics 2011, 30, 5753-5762; c) F. Calderazzo, G. Dellamico, M. Pasquali, G. Perego, Inorg. Chem. 1978, 17, $474-479$.

[25] CCDC 1587291, 1587292, 1587293, and 1814913 contain the supplementary crystallographic data for this paper. These data can be obtained free of charge from The Cambridge Crystallographic Data Centre.

Manuscript received: January 6, 2018

Accepted manuscript online: January 25, 2018

Version of record online: March 5, 2018 